\title{
The Experience of Regional Planning of the CESP (Companhia Energética de São Paulo), Brazil
}

\author{
Mônica Peixoto Vianna \\ Institute of Architecture and Urbanism, University of São Paulo, São Carlos 13566-590, Brazil
}

\begin{abstract}
This article deals with the important experience of regional planning developed by the CESP (Companhia Energética de São Paulo), Brazil, through the implantation of its hydroelectric projects. The company accumulated a large experience in deploying and managing residential centers built to provide support to the works of their dams. The presence of urban planning was verified in all cases studied, with the participation of different professionals such as architects, planners, engineers and landscape designers, from inside or outside the company. This research shows that they used concepts derived from experiences as company towns of 19th century, the neighborhood unit, the garden city, the urbanistic assumptions from CIAM (Congrès Internationaux d'Architecture Moderne) and the TVA (Tennessee Valley Authority).
\end{abstract}

Key words: CESP, regional planning, residential villages, TVA.

\section{Introduction}

During the 1940s and 1950s, the prevailing thought was that, in Brazil, the regional planning could supply the country with the means of overcoming the existing infrastructural deficiencies which would boost the process of national industrialization. However, there was the need to finance the desired national development. Stood out at this time, the various foreign missions, specially American, who made surveys on the Brazilian reality with the aim of pointing out the weaknesses of the economy in order to correct them though government measures. The investments made in Brazil came primarily to meet the transport and energy sectors, and only then, to finance the domestic industry. In this context of investments in infrastructure, in which some studies aiming territorial planning and the state plans were developed, the first public hydroelectric plants were built as well as their support works, and were organized the first public companies to generate electricity in Sao Paulo.

Within the developmental stage of the Brazilian

Corresponding author: Mônica Peixoto Vianna, Ph.D., research fields: regional planning, company towns, industrial heritage and hydroelectric sector. E-mail: monica_vianna@yahoo.com. economy and its political constraints, began the government's participation in the production of electricity. The energy as a strategic sector for the process of industrialization was one of the priority items on the agenda of the country in national developmentalism. The American references followed in the administrative reform undertaken by the president Vargas contributed to the emergence of a new concept of organization of industry in urban municipalities, a new profile of the professional planner as well as new conceptions of urban plans and the legislation. The CESP (Companhia Energética de São Paulo) appeared, therefore, in the context of the big bet in planning and direct action of the state creating the foundation for economic development, land occupation and urban regulation.

\section{The Experience of Regional Planning}

The deployment of state-owned electricity companies in Brazil has resulted, in 1966, in the CESP, through the merger of five state-owned companies with six others, originally privates. At that time, Brazil already had a long experience of creating company towns including projects by planners. Thereafter, the 
company began performing all stages of production, from the feasibility studies of the exploitations of natural resources for power generation, to his household distribution. During consolidation, CESP formed interdisciplinary frameworks geared to the study, the analysis, the evaluation and the application of criteria, guidelines, plans and programs to suit the territories affected by their activities. The division of architecture and urbanism of the CESP, formed to complement the activities of engineering, drew from his own experience of designing guidelines for managing the work of the project companies, often taking decisions in the field of his specialty.

\subsection{The Importance of the Regional Context in This Experience}

The division had three scales that were used to define the methodological approach to land planning and urban design as also the architecture of the hydroelectric plants. The first one, broader, involves the entire basin, which investigated the significance of the presence of several dams in place, in relation to the pre-existing situation. Another, of regional character, that sought to reconcile the regional uses of the reservoir and surrounding areas. And the third, of local expression, which cared for the direct impacts produced by the dam construction around it, balancing the deployment of infrastructure support and recasting the landscape damaged by works [1].

Over time, various proposals have been developed for different parts of the hydropower projects, such as accommodation for their workers, community buildings, the villages of operators, construction sites and offices, the power houses, the houses of command, the command of the sluice, the substations and even broader interventions beside the reservoir, such as resettlement of populations and activities, the road system, the landscaping, forestry and fish farming. The fixation of the workers required solutions that would enable meeting their basic needs during the part of their lives they would live at the construction sites and simultaneously control the impact produced in urban centers close to work [2].

Although they represent relatively small share of major undertaking, the works of support shifted considerable resources, requiring administration and long-term vision, in order to minimize costs of decommissioning equipment transient, recovering areas of construction sites and enable reuse all or part of buildings in future works. Increasingly, the set of additional works influenced in achieving the major undertaking, requiring appropriate strategies to mitigate the effects of such interventions [3].

The large disparities between several regions and the peculiarities of each hydroelectric project made it difficult to establish general guidelines for the deployment and management of residential villages. Thus, the socio-economic conditions of the region where the dam was located, the nearby towns, the regional road system, the need to reconcile the interests involved and the concern to ensure the best return on investment guided the choice of solution. However, the company's experience in the construction of villages and workers' housing, was organized around three basic models of action, showing awareness of the need for socio-economic optimization of investments in order to integrate them in a frame regional development.

The first was the construction of a residential village near the construction site and isolated from the existing urban structure, in a strategic position that facilitated the control and the increased productivity, since employees were placed in constant readiness for the job. This model was constructed, for example, to operators of the HPP (hydroelectric power plants) of Barra Bonita, Bariri, Ibitinga, Limoeiro, Jurumirim, Salto Grande and Paraibuna.

Another adopted option was the establishment of a permanent workers' housing in regions where, normally, the rarefaction of the urban network prevented the use of nearby cities such as support. This center should be equipped with all the 
infrastructure needed for its full operation and autonomous, becoming a center of future development for the region, which actually happened in Ilha Solteira-firstly implanted as camp and then converted into a city—and Porto Primavera-already established as an "open city"1.

Another possibility was to use a mixed solution where part of the village would be permanent and the other one would be removed after completion of work, such as the hydroelectric plants of Bariri, Ibitinga, etc.. Thus, the permanent part should be sized according to the regional development plan and the company's need to accommodate the power plant operators. This solution had the advantage of eliminating the implications of the decommissioning of works and the reuse of part of the buildings.

Finally, CESP has also made use of a model that adopted the occupation of nearby towns when the urban structure behaved, either by rental or building houses. This solution was well accepted, since it would pass most of the cost to the infrastructure for the region, minimizing the implications that would arise in the deactivation of these works support, being used during construction of the hydroelectric plants of Água Vermelha, Capivara, Nova Avanhandava and Taquaruçu. In this case, firstly the Companhia considered the rental of existing homes in nearby towns, after this, the construction of houses, and finally, the construction of village annexed to the city nearest existing, if possible it should be pre-fabricated.

\subsection{The Stages of Architectural Design in This} Experience

Consequently, the architectural design of CESP plants were grouped in stages according to their means

\footnotetext{
${ }^{1}$ The development of the project of workers' housing, next to construction sites, depended on government interests in deploying a permanent site. Such an attitude would allow transfer to the region, after the completion of the plant, the improvements made. If this interest did not manifest itself, the alternative was to build a village of a temporary nature, using construction techniques that would allow its removal, as occurred with the camp of Jupiá.
}

of production and arranged chronologically by opening date, according to the classification:

(1) In the first group, were included the hydroelectric plants of Salto Grande (1958), Jurumirim (1962), Barra Bonita (1965), Bariri (1967) and Ibitinga (1969), whose projects have been accompanied by the architect Hélio Pasta (1927), according requests from the engineer Mario Lopes Leão (1912-1980). At the same time, the engineer Ernest Robert de Carvalho Mange (1922-2005) participated in the design of the hydroelectric plants of Limoeiro (1958), Euclides da Cunha (1960) and Caconde (1966), in the valley of the Rio Pardo, and then, in the hydroelectric plants of Jupiá (1969) and Ilha Solteira (1973), included in the second block [1];

(2) Then, came the first phase of the Division of Architecture of the CESP, with the hydroelectric plants Chavantes (1970), Mario Lopes Leão (1975) and Capivara (1977), developed by the staff of the Division, along with the collaboration of Julius Katinsky (1932) in Chavantes. At the same time, the hydroelectric plants of Jaguari (1972), Paraibuna-Paraitinga (1978) and Água Vermelha (1978) were also designed [1];

(3) Finally, the group of hydroelectric plants of Nova Avanhandava (1978), Rosana (1987), Taquaruçu (1992), Três Irmãos (1990) and Porto Primavera (1994), representing the time when the technological development of the CESP was shared by several firms designers of the electricity sector, also Canoas I and II, São José and Carrapatos, and, more recently, the restoration of the hydroelectric plant of Corumbataí (Figs. 1 and 2) [1].

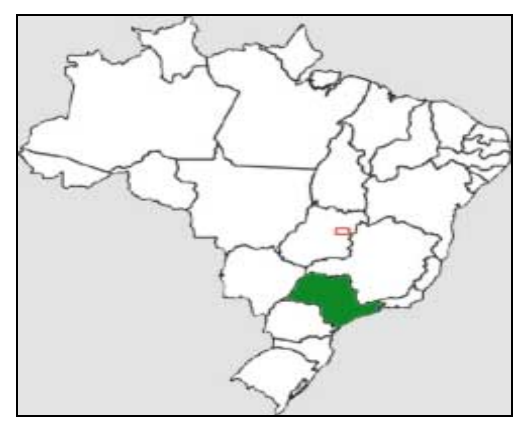

Fig. 1 Map of Brazil highlighting the state of Sao Paulo [4]. 


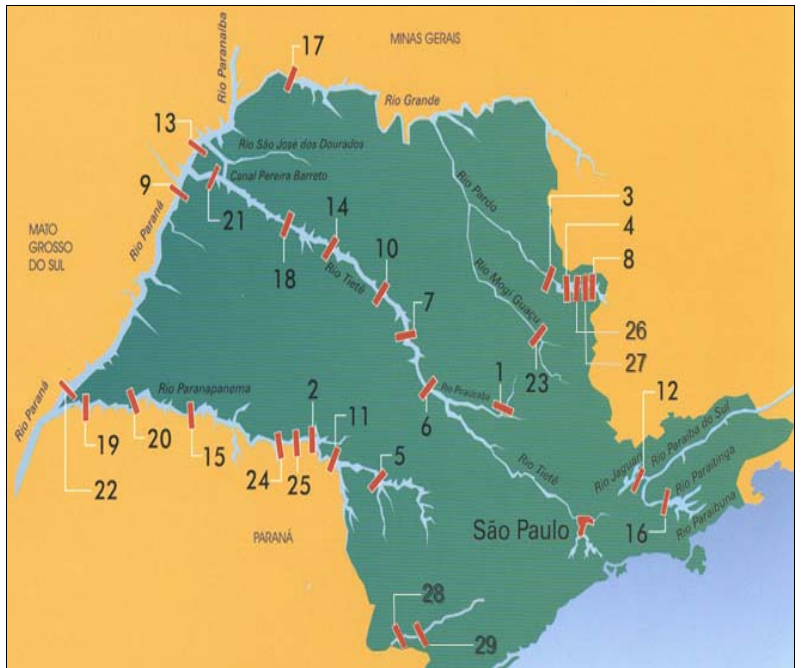

Fig. 2 Location of CESP's hydroelectric power plants in state of Sao Paulo, in chronological order ${ }^{2}$.

\subsection{Some Examples of This Type of Regional Planning}

In the first hydroelectric plants in the 1950s and 1960s, the concessionaires from the state of São Paulo built and maintained residential villages for their own workers, usually in privileged areas near the future lake, and that after the completion of the works were intended to accommodate the plant operators and their families.

The larger hydroelectric projects located in remote parts of the state, needed a very large number of workers, promoting the approach to the issue of accommodation with a vision of urban planning, considering also the minimal needs of community facilities. In the works of this period, the largest group

2 In chronological order by opening date: 1. Corumbataí (1900), 2. Salto Grande (also known as Lucas Nogueira Garcez, 1958),

3. Limoeiro (also known as Armando de Salles Oliveira, 1958),

4. Euclides da Cunha (1960), 5. Jurumirim (also known as Armando Avelanal Laydner, 1962), 6. Barra Bonita (1963), 7. Bariri (also known as Álvaro de Souza Lima, 1965), 8. Caconde (1966), 9. Jupiá (also known as Eng. Souza Dias, 1969), 10. Ibitinga (1969), 11. Chavantes (1970), 12. Jaguari (1972), 13. Ilha Solteira (1973), 14. Promissão (also known as Mário Lopes Leão, 1975), 15. Capivara (also known as Escola de Engenharia Mackenzie, 1977), 16. Paraibuna (1978), 17. Água Vermelha (also known as José Ermírio de Moraes, 1978), 18. Nova Avanhandava (1982), 19. Rosana (1987), 20. Taquaruçu (also known as Escola Politécnica, 1989), 21.Três Irmãos (1993), 22. Porto Primavera (also known as Eng. Sérgio Motta, 1999), 23. Mogi-Guaçu (1999), 24. Canoas I (1999), 25. Canoas II (1999), 26. São José (1990’s), 27. Carrapatos (1990’s), 28. AM Funil (1990’s) e, 29. AM Batatal (1990’s). of workers, connected to the firms contractors, was housed in camps near the construction site, under the direct responsibility of these companies, and in many cases, creating social problems and of working relationships ${ }^{3}$. In these construction sites, both employees of dealerships as the contractors were treated equally, according to the function they performed, and the accommodation spaces were designed not only with housing but also with the collective facilities (health centers, schools, consumer cooperatives, sports and recreation areas and other public services), providing better living conditions.

An important milestone of the first phase, both for its size as by its scale was the construction of the camp of Jupiá, 1961, on the Parana River. According to the distance of the work to larger urban centers in the region and the lack of skilled labor available, was decided by the establishment of a camp and a village of operators near the construction site of the plant. The community facilities were designed so as to be complementary to the region. Due to its size, the camp of Jupiá (Fig. 3), with its rigid layout concentric, established itself as a true urban center, reaching the number of 14,000 inhabitants. Nevertheless, he had a temporary character since the work was completed the camp was removed, leaving only the village of the hydroelectric plant operators. Its removal, between 1969 and 1970, did not increase the cost of the hydroelectric plant, but failed to pass any benefits to the region that, in the long term, his stay could have generated. Administratively, it was characterized as a community "closed" under control of the company, which eventually turn the inhabitants into citizens protected, since compromising the spontaneity of

\footnotetext{
3 The implementation period of the camp depended on a set schedule for the implementation of the hydroelectric plant. The work schedule of the camp was a direct function of the distribution of manpower during the construction of the plant, as the peak of workers that occurred usually in the third year of construction, the camp should be fully ready by the beginning of this year. This is a peculiar feature of the camps of dams: The speed with which they are deployed cities for 10,20 or 30 thousand people and that are fully built and run on only two or three years [5].
} 
social relations [3].

The most relevant example of the second phase was the residential village of Ilha Solteira, 1967, which reached 30,000 inhabitants, on the period of peak concentration of workers (Fig. 4). Deployed on a permanent basis at a cost equivalent to a temporary, had the aim to transfer the improvements generated with its creation to the region. It was characterized as an intermediate model between the camp organization and the structure of a city that was a community a little more open, in which the worker was still very protected by the CESP. This was the first experience of a permanent urban agglomeration, aimed initially to house the population of workers involved in a work, which later would become an independent municipality. At the end of the 1980s, Ilha Solteira has had a population of about 25,000 inhabitants and became a center for regional development [3].

The urban network and the socioeconomic characteristics of the region allowed the Companhia to adopt a different model of support for the construction of the HPP of Água Vermelha, 1978, becoming a reference, in this case, of the third stage. Instead of building a new city, they chose to use the cities near and include in them the housing and the necessary equipment (Fig. 5). The single employees were housed in camps near the construction sites and the married ones, with their families, occupied dwellings in five towns. After the completed works of the hydroelectric plant, the benefits generated by the presence of CESP—roads, pavements, water, sewerage, electricity, school, hospital, club-were incorporated by the communities. The permanent dwellings were sold or occupied by the hydroelectric plant operators, and the transitional ones were fully transferred to other work ${ }^{4}[6]$.

\footnotetext{
${ }^{4}$ The results, judged satisfactory, of the model adopted in Água Vermelha-previously experienced in Capivara, 1976 - contributed to its reproduction in Nova Avanhandava, in 1982, where the regional urban network ensured the absorption of the works of support. At the end of the work, the villages integrated into the residential cities were turned off without difficulty [3].
}

The works of the hydroelectric plants of Porto Primavera and Rosana, 1980, showed great peculiarities. The ownership and low quality of land generated the delayed of occupation and development of the region. Verified the impossibility of having any support of the cities available, the authors resorted to the establishment of a city capable of hosting a population of 25,000 , needed to build the two plants. Thus, was designed a residential villages that would have a core of 1,500 permanent homes, surrounded by a ring with 3,000 prefabricated housing, fully collapsible, subject to partial or total removal. This ring gave conditions to the village of Porto Primavera adjust its size according to future stimuli and local needs (Fig. 6). Basic services were assumed by the

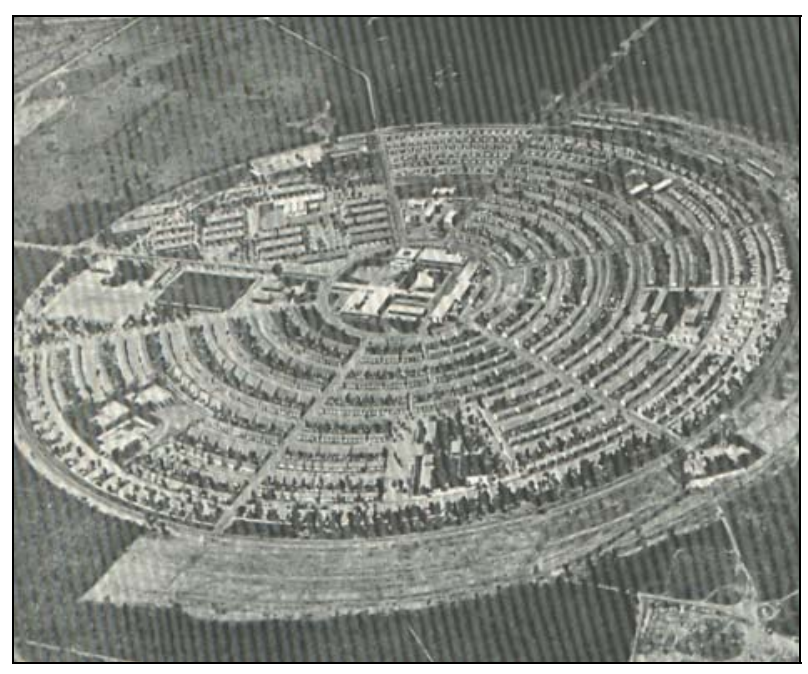

Fig. 3 The camp of Jupiá, 1963 [6].

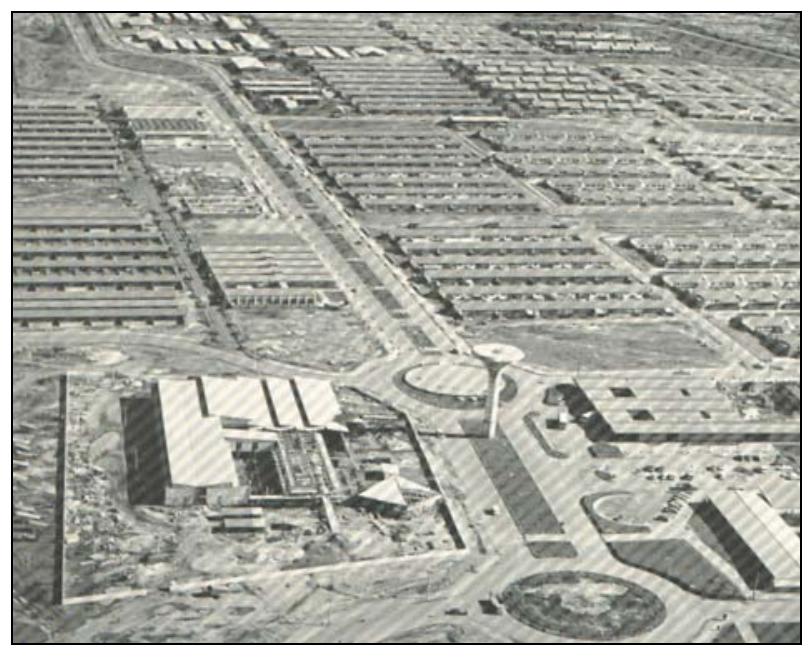

Fig. 4 Residential village of Ilha Solteira, 1967 [7]. 


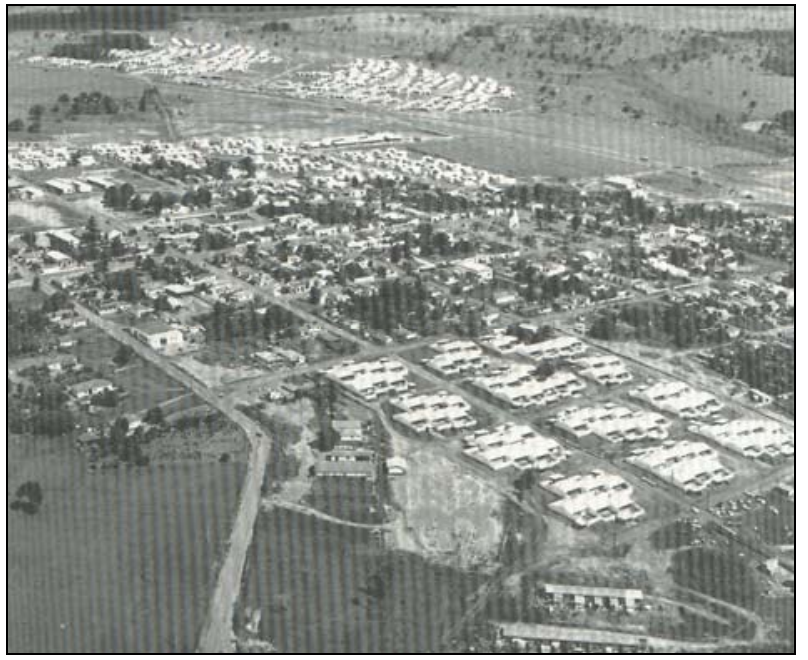

Fig. 5 Workers' housing in the city of Indiaporã to the work of the hydroelectric plant of Água Vermelha, 1978 [3].

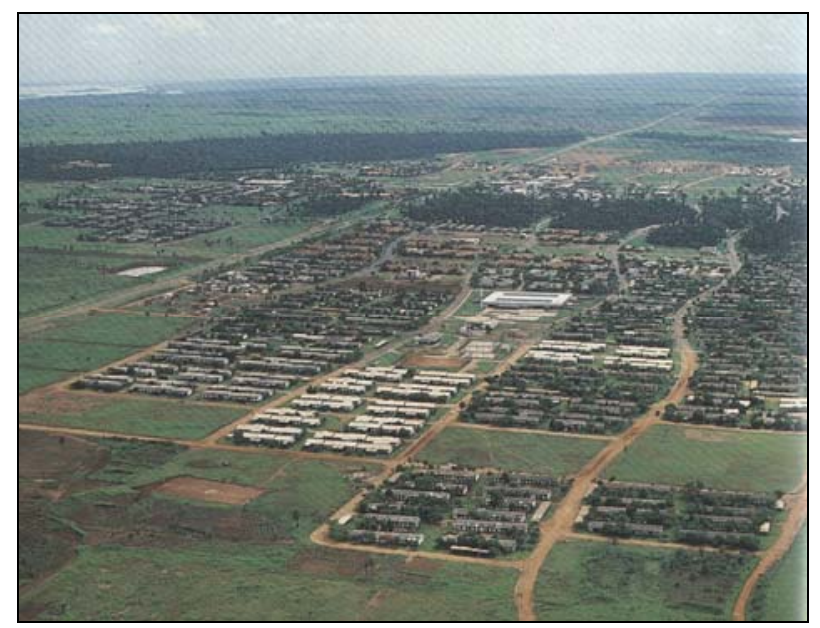

Fig. 6 Residential core of Porto Primavera [3].

respective institutional bodies and the tight control adopted in the previous examples was abandoned. The workers were no longer protected and the free participation of the private sector was guaranteed, constituting what might be called an "open city" [3].

\section{Architecture in CESP}

The origin of the residential villages of CESP was the works of hydroelectric plants, mostly, executed or initiated earlier by the dealers. The architecture in the company followed two convergent paths: the architect Hélio Pasta and the engineer Robert Mange. The contribution of Pasta is expressed in the works of USELPA (Usinas Elétricas Paranapanema), and of Mange, in the CHERP (Companhia Hidroelétrica do
Rio Pardo) and CELUSA (Centrais Elétricas de Urubupungá S.A.), through his private office of architecture, Planemak (Planejamento Edifícios e Cidades. Inc.), in partnership with the architect Ariaki Kato (1931).

Over time, CESP established itself as a major sponsor of architecture, whose hydroelectric projects have created the opportunity for experimentation "strongly impregnated by technical rationalism, a materialization of modernist idealism of the 1920s in which architecture should represent the new industrial society" [8].

At this time also happened the spread of the figure of the architect and urban planner as developer of integrated projects in the electricity sector, being responsible not only for the activities related to additional works and buildings, but for the spatial organization and constructive details of major works. In Brazil, the architects worked initially as service providers to state enterprises, and gradually, were incorporating to the paintings of the companies.

In the United States, the emergence of company towns was important to the redefinition and upgrading of the professional of the project area ${ }^{5}$, just as, years later, the American experience of the TVA (Tennessee Valley Authority) was decisive in introducing aspects related with the integrated planning and the multiple use of watershed, along with hydropower projects.

In Brazil, the American experiences influenced in the recovery of this profession by highlighting it within a framework dominated until then by engineers. In CESP, the architect and his team were not only responsible for activities related to additional works and buildings, but also interfered with the spatial organization of the whole and in the constructive details of major works of the hydroelectric plants. The experience of the division of architecture from

\footnotetext{
${ }^{5}$ In relation to this change in the form of participation of architects in large enterprises, Margaret Crawford analyzes the condition of design professionals and shows how important had been the redesign and the deployment of industrial centers as a way to expand their professional fields. The company towns offered this opportunity for architects [9].
} 
Companhia may also be considered exemplary by the scientific and technological research that has developed.

The professional field of architecture in the enterprises from CESP has become very broad, ranging from the activities proper to interdisciplinary integrated planning of the reservoirs to the physical organization of the administrative areas through design of the hydroelectric plant and their supporting works such as the accommodation for single employees and housing units. These facilities, if transitional, ended up being designed with such quality that admitted its removal, when necessary, with a minimum loss at the end of the works. The architects were also responsible for pioneering proposals of landscaping, gradually assimilated by the company at the hydroelectric plants, in the 1960s, to finally achieve the landscape-ecological surrounding the reservoir, in the 1970s and 1980s.

From the effective participation of its division of architecture, the Companhia and its consultants hired were pioneered the involvement of architects in the feasibility studies of hydropower. Since the integrated regional planning to the functional and formal proposals for solving structures of hydroelectric plants and its surroundings, the division participated increasingly integrated with the professionals of engineering and of environmental projects in the formulation of the inventory and feasibility of projects hydropower.

Hydroelectric projects of this period served as support for architectural experimentation, strongly impregnated by technical rationality, in an embodiment of modernist ideas of the twenties, in which architecture should represent the new industrial society-iconically symbolized in the speeches of Le Corbusier (1887-1965) and Walter Gropius (1883-1969), in factories or silos. The dam, the power house and the control room restored this imagery, relating modern architecture to the industrial building [8].

\section{References for Planning}

It was verified the presence of urban planning in all cases studied, with the participation of different professionals such as architects, planners, engineers and landscape, from inside and outside the division ${ }^{6}$. It was made the use of a functionalist architecture, with the presence of industrial materials that rationalized the building, trying to adapt it to the climate and the manpower of the regions in which the enterprises were located.

Is was possible to see how the first residential villages built by CESP and its predecessors have adopted procedures for the spatial organization from the company towns developed throughout the development process of modern industry, from the late 18th century. This experience highlighted the isolation-location in the field, near the lakes of the hydroelectric plants—and the autonomy of the village; the provision of conditions-housing, social facilities and infrastructure in solidarity with labor productivity, the social division of space-physical separation between dwellings and eventually also between hotels and clubs for the various social classes and functional categories, the difference in the pattern of houses - the predominance of single-family homes, the segregation of single employees, the control of the worker's free time, the forms of labor management, the presence of green etc.. Over time, some features have been changing, especially with respect to supervision by the company on the core, which has already started to be built on a permanent and open character.

The concept of "neighborhood unit" was present in almost all settlements of CESP, in relation to the definition of programs, the location of the houses, local shops and equipment for collective use. This

\footnotetext{
${ }^{6}$ CESP has established rules of professional interaction with standalone colleagues on several occasions, invited to collaborate, such as Oscar Niemeyer (1907), Vilanova Artigas (1915-1985), Fernando Chacel (1931-2011), Paulo Mendes da Rocha (1928), Ruy Otake (1938) and others who did projects for different parts of the company.
} 
concept also influenced the organization of the road system-prioritizing routes for pedestrians and protecting the interior of the vehicle traffic - at the disposal of construction and distribution of uses, especially in schools and kindergartens.

The postulates urban broadcasted by the CIAMs (Congrès Internationaux d'Architecture Moderne), could also be identified through the ideas of the city considered in the region, of the urbanism as planification, functional cities, zoning laws, the concern with densities and rational and efficient methods of construction, with types of buildings, with the concept of "core" etc..

And finally, the American experience of the TVA, 1933, one of the initiatives included in the Roosevelt New Deal government, in relation to aspects of integrated planning and multiple uses of watershed, expanding the goals of the enterprises and opening new perspectives for the professional participation of architects.

The performance of the authority summarized urban, ecological, architectural, social and educational concerns, within the multiple objectives such as: improved navigation and flood control through dams coupled to hydro so as to permit the electrification of the region, and modernize and make profitable farms and thus develop agriculture [10]. Two expressions began to gaining prominence from that time, in several modern languages arising from this experience: "interdisciplinarity", for research, and "multiple use" (multipurpose), for certain goods, including in our case, the reservoirs resulting from dams, since they were designed to regulate the flow of rivers by preventing the devastating floods, to ensure a steady supply of water for irrigation to ensure the IWTtransport cheaper-per ton/kilometer transported, to provide the pisciculture, both recreational and commercial, and also, forecast for the recreational use of its banks and ground water [11].

The integrated regional planning in Brazil may have its onset associated with the major repercussions obtained by the regional plan of the Tennessee Valley in the United States, which was widely circulated as a model of democratic regional planning. This assertion can be demonstrated by the creation of several bodies at the national level, following the trend pointed.

By the 1950s, in the stage of development of the economy and its political conditioners, began the government's participation in the production of electricity. Measures taken during the second government of Getúlio Vargas, from 1951 to 1954, along with the "Target Plan” of Juscelino Kubitschek, from 1956 to 1961, and the favorable international conditions, enabled a great expansion of the infrastructure of power generation. The energy as a strategic sector for the process of industrialization was one of the priority items on the agenda of the country in National-Developmentalism. The Initiatives similar of regional planning in Brazil, although have been inspired by the experience of the TVA, it was not reproduced in full.

\section{Conclusions}

A true heritage of public administration of TVA can be seen in Brazil's hydroelectric plants, in which one observes the spirit of development and modernization carried out by land occupation and exploitation of hydraulic potential, in the role of architects in the programs of technical facilities and operational planning of hydroelectric plants, and the project teams who now have professionals from various fields, working together and creating new ways of development projects. The subsequent work of many architects and the recognition of the importance of participation in this professional sector characterized the first decades of the implementation of power sector in the country and are important until today.

The CESP has accumulated a reasonable experience in deploying and managing residential villages built to provide support to the works of their dams. It was verified the presence of urban planning in all cases studied, with the participation of different professionals such as architects, planners, engineers and landscape, inside and outside the division. Thus, it 
projected a functionalist architecture with industrial materials that rationalized the building, trying to adapt it to the climate and manpower of the regions in which the enterprises were located. The author can say that the concepts derived from experiments such as the company towns of the nineteenth century, the neighborhood unit, the garden city, the postulates urban broadcasted by CIAM and also the TVA, were important as initial inspirations for CESP. However, over time, the company developed a proper method of integrated regional planning [12].

The subject of the regional planning undertaken by the electricity sector, especially in the state of Sao Paulo, has been insufficiently researched in Brazil, which opens a wide field of research in this area, both for architects and engineers.

\section{Acknowledgments}

The author would like to thank to FAPESP (Fundação de Amparo à Pesquisa do Estado de São Paulo) for the financial support for the research.

\section{References}

[1] N.M.J. Tsukumo, Arquitetura das usinas hidrelétricas: A experiência da CESP, São Paulo, Master Thesis,
Universidade de São Paulo, 1989.

[2] CESP Divisão de Arquitetura e Urbanismo, Vilas Temporárias e Permanentes do Setor Elétrico: A Experiência da CESP, CESP, São Paulo, 1982.

[3] N.M.J. Tsukumo, Architecture at CESP, CESP, São Paulo, 1994.

[4] M.P. Vianna, From the building to the urban layout: The experience of integrated regional planning in CESP, Ph.D. Thesis, Universidade de São Paulo, São Carlos, 2012.

[5] W. Jorge, Acampamento de obras hidroelétricas: Estratégia para sua utilização como núcleos urbanos permanentes, Master Thesis, Universidade de São Paulo, São Paulo, 1979.

[6] H. Pasta, A Arquitetura nas UHE’s: A Experiência da CESP, CESP, São Paulo, 1985.

[7] Ilha Solteira: a Cidade e a usina, Fascículos de História da Energia Elétrica em São Paulo, CESP, São Paulo, 1988.

[8] H. Segawa, Arquiteturas no Brasil 1900-1990, Edusp, São Paulo, 1999.

[9] M. Crawford, Building the Workingman's Paradise, The Design of American Company Towns, Verso, London and New York, 1995.

[10] D. Lilienthal, TVA: Democracy on the March, Harper \& Brothers, New York, 1944.

[11] J.R. Katinsky, Das Pequenas Usinas às Grandes Barragens, Sinopses, São Paulo, June 1997, pp. 22-30.

[12] M.P. Vianna, Workers housing at CESP: The process of dismount, São Carlos, Master Thesis, Universidade de São Paulo, 2006. 